\title{
Naujojo viešojo valdymo modelių paieškų analizė
}

\author{
Alvydas Raipa \\ Kauno technologijos universitetas \\ K. Donelaičio g. 20, LT-44239 Kaunas \\ crossref http://dx.doi.org/10.5755/j01.ppaa.10.3.647
}

Mcnabb E. David. The New Face of Government. How Public Managers Are Forging a New Approach to Governance. New York: CRC Press, 2009. Globali dabartinio laikotarpio viešojo gyvenimo kaita suponuoja viešojo valdymo pokyčius, jo sistemų struktūrinę kaitą, naujų viešojo valdymo formų atsiradimą, naujus vykdomosios valdžios ịstaigu veiklos standartus, didesnius reikalavimus viešojo valdymo institucijoms ir personalo gebejjimams. Šie pokyčiai, vykstantys paskutinių dviejų dešimtmečių laikotarpiu, sąlygojo daugiau kaip šimtmetị vyravusios tradicinio viešojo administravimo doktrinos kaitą ir ịvairių jos modernizavimo formų naujosios viešosios vadybos, naujosios viešosios tarnybos, naujojo viešojo (gerojo, modernaus) valdymo - atsiradimą. Ištikus pasaulinei ekonominei-finansinei krizei ir atsiradus globaliesiems konfliktams, reikia naujo valdymo ir naujų valdymo specialistų kompetencijų, motyvacijos ir gebejjimų suvokti viešojo valdymo transformacijų strateginius prioritetus, kryptis ir nustatyti tendencijas.

Analizuodamas daug šiuolaikinio viešojo valdymo modernizavimo klausimų, D. E. Mcnabbas yra vienas iš nedaugelio šiuolaikinių teoretikų (greta St. Osborne, J. E. Lane, M. Spicerio, M. Holzerio ir kt.), kuris viešojo valdymo pokyčių analizės struktūroje sėkmingai taiko metaanalizès ir atvejų analizès metodų suderinamumą, siekdamas paaiškinti viešojo valdymo pokyčius, remiantis viešojo valdymo evoliucionavimo metodologinėmis prieigomis. Taip pat sugeba išskirti viešojo sektoriaus organizacijų vidinès ir išorinès aplinkos ir jų sąveikos dimensijas, padedančias sudaryti nustatytinès ir plètotinès metodologijų (t. y. metodologijų, leidžiančių numatyti galimas valdymo evoliucionavimo pasekmes ir prognozuoti rezultatus, remiantis ịvairiarūšiais ekstrapoliacinių metodologiju variantais) kaitos strategines kryptis, priemones ir procedūrinius-normatyvinius algoritmus. Recenzuojamos knygos autorius yra vienas iš nedaugelio viešojo sektoriaus šiuolaikinių pokyčių tyrinètojų, puikiai derinančių sisteminę procesų tyrimo prieigą, naudojantis ịvairių lygių (mikro-, mezo-, makro-, meta-, mega lygių) viešojo valdymo analizės lygmenų informaciją, remdamasis valdymo problemų struktūravimo metodologijos galimybėmis. Autorius puikiai formuoja originalias įžvalgas ir kuria konkrečias organizaciniu pokyčių valdymo modeliavimo galimybes, apimančias tiek organizacinès struktūros, tiek organizacinès kultūros, tiek organizacinès elgsenos (administracinio mąstymo) konstrukcijas, kurias tam tikra prasme galima sieti ir su $\mathrm{H}$. Simon XX a. vidurio „administracinio žmogaus“ ir „administracinès valstybès“ teorinių konstrukcijų apibendrinimu dabartinèms sąlygoms (p. 48-56). 
Recenzuojamos monografijos apimtis - 280 p. Autorius ją skiria „tūkstančiams valstybės tarnautojų, kurie kasdien laikosi gero viešojo valdymo principų“. Knyga itin kokybiškai parengta turinio logikos požiūriu, pavyzdinė monografijos technologinè leidinio kokybė. Monografijoje panaudota daugiau kaip 400 ịvairių autorių knygų ir mokslinių straipsnių, kurių daugiausia publikuota 2000-2008 m. laikotarpiu. Knygoje daug vertingų schemų, paaiškinimų, lentelių ir paveikslų, kuriais viešojo sektoriaus tarnautojai ir vadovai gali pasinaudoti pasirinkdami prioritetines veiklos kryptis.

Monografijoje 14 skyrių. Taip smulkiai išskaidžius problemas galima detaliau atlikti lyginamają teorinių ir ypač praktinių atvejų analizę. Antra vertus, kai kuriuose skyriuose yra vos po 10-15 puslapių. Kiekvienas skyrius suskirstytas vidutiniškai i 15-20 poskyrių, kuriu apimtis yra vos 1-2 puslapiai, todèl kartais pasigendama platesnio struktūrinių elementų ịvardijimo, gilesnès organizacinès aplinkos analizės ar valdymo pokyčius detalizuojančių apibrèžimų paaiškinimų. Tačiau tyrimo logikos, kuri sąlygoja ir darbo struktūrą, pasirinkimas yra tik autoriaus prerogatyva, todèl recenzento nuomonè negali būti bent kiek kategoriškesnè.

Monografijoje atskirai išskiriamos viešojo sektoriaus procesų pokyčių valdymo technologinio aprūpinimo, operacinių sistemų ir jų modifikavimo ir modernizavimo problemos. Pokyčių vertinimas, organizacinès kultūros veiklos procesų indikacijos ir modernizavimo efektyvumo parametrų paieška yra vienas iš svarbiausių autoriaus tikslų. Monografija yra vienas iš sẻkmingu kompleksinių naujojo viešojo valdymo struktūrinès analizès pavyzdžių. Ši analizè solidžiai papildo itin negausias pirmąsias viešojo valdymo teoretikų pastangas: siekiama pažinti besiformuojančios ir evoliucionuojančios naujojo viešojo valdymo doktrinos galimybes, formuojami valdymo pokyčių strateginiai imperatyvai, analizuojamos naujo viešojo valdymo galimybės, kuriamos praktinès rekomendacijos ir ižvalgos, kad valstybės instituciju veikla būtų nukreipta aptarti problemas, institucijos galètų koordinuoti savo sprendimų rengimą, igyvendinimą, kad būtų koordinuojama visų lygių ir rūšių institucijų veikla, kad būtu siekiama ìveikti pasaulinès ekonominès finansinès krizès pasekmes, tarptautini terorizmą, kad būtų sprendžiamos globalios migracijos, pasaulio religijų santykių problemos.

Viešojo valdymo specialistai recenzuojamoje monografijoje turès galimybę susipažinti su naujausiais tyrimais, skirtais XXI a. pirmojo dešimtmečio valdymo pokyčių struktūrinių elementų nustatymui, su originaliais viešojo valdymo pokyčių keturiais lygmenimis, pagrịstais organizacijų veiklos vertinimo ir stebėsenos metodologijų galimybėmis, identifikuojant pokyčių struktūrinius elementus, nustatant veiklos procesų tobulinimo kriterijus, numatant pokyčiu perspektyvas ir socialinès elgsenos pokyčių reikšmes, sudarant viešojo valdymo pokyčių rezultatus ir tolesnes šiu procesų perspektyvas (p. 15-22).

Analizuodamas ịvairių viešųų sektorių (energetikos, sveikatos apsaugos, susisiekimo ir kt.) infrastruktūrinius valdymo pokyčius, monografijos autorius ypatingą dèmesi skiria organizacinei kultūrai, t. y. naujų demokratinio organizavimo valdymo krypčių analizei, kolegialaus valdymo, kaip vieno iš svarbiausių viešojo valdymo bendrųjų principų, naujam suvokimui, įprasminant 
entreprenerystės tradicinès sampratos derinimą su naujomis viešojo valdymo bendradarbiavimo ir partnerystès su privačiomis ir nevyriausybinèmis organizacijomis formomis, organizacijų veiklos tradicinius imperatyvus su naujais iššūkiais organizacinès kultūros pokyčiams, išryškinant objektyvų organizacijų poreikị juos itvirtinti (p. 41-44). Ypatingas dèmesys skiriamas atskiru ,gerosios patirties“ atvejų analizei, kada remiantis naujojo viešojo valdymo elementų struktūros nustatymu atliekama organizacijų veiklos pokyčių ir pokyčių poreikių struktūrinè analizė, tiriamas žmogiškojo kapitalo vaidmuo pokyčių valdyme, nagrinėjama piliečiu dalyvavimo, lyderystès, naujo tipo organizacinių struktūrų, multiorganizacinès kultūros formavimo vieta pokyčiu valdymo kontekste (p. 70-83).

Atskirais pokyčių valdymo viešajame sektoriuje aspektais pateikiami įdomūs ir vertingi svarstymai apie technologijų ir technologinių sistemų poveiki viešojo valdymo pokyčiams, jų įtaką institucijų struktūros pokyčiams ir naujiems viešojo valdymo pertvarkos sprendimams, pokyčių valdymo strateginių nuostatų kūrimui ir jų igyvendinimo metodų ir procedūrų prisitaikymui viešojo sektoriaus struktūrinèje ịvairovèje.

Recenzuojamoje monografijoje pateikta medžiaga geriau suvokiama tik turint atitinkamą viešosios politikos ir viešojo valdymo teorinị pagrindą. Todèl daugiausia ji gali būti naudinga vadybinès ir politinès administravimo krypties doktorantams, aukštujų mokyklų dèstytojams, valstybès tarnautojų lavinimo institucijose dirbantiems specialistams, viešojo valdymo ekspertams, tarp jų valstybės ir šakinių strategijų rengejjams.

Tikiu, kad recenzuojama D. E. Mcnabbo monografija prisidès prie kokybiškesnių, visapusiškiau pagrịstų viešojo valdymo sprendimų rengimo, racionalesnio viešojo valdymo teorinių principų interpretavimo, naujo modernaus visų rūšiu ir tipų organizaciju socialinès atsakomybès už valstybės institucijų, valstybės piliečių ateitị suvokimo ịtvirtinimo.

Alvydas Raipa - Kauno technologijos universiteto Socialinių mokslų fakulteto Viešojo administravimo katedros profesorius, socialinių mokslų daktaras.

E. paštas: alvydas.raipa@ktu.lt

Alvydas Raipa, Doctor of Social Sciences, is a Professor at the Department of Public Administration of the Faculty of Social Sciences, Kaunas University of Technology. E-mail: alvydas.raipa@ktu.lt

Apžvalga įteikta redakcijai 2011 m. liepos mèn. 